\title{
The Structure of Cell Walls of Phycomycetes
}

\author{
By MONIQUE NOVAES-LEDIEU AND A. JIMÉNEZ-MARTÍNEZ \\ Instituto de Biologia Celular, C.S.I.C., Madrid-6, Spain
}

(Accepted for publication 5 August 1968)

\begin{abstract}
SUMMARY
Dilute acid treatment of isolated hyphal walls from Phytophthora heveae and Pythium butleri separates two fractions: an acid-soluble carbohydrate protein containing glucosamine (about three-fifths of the total glucan weight) and an acid-insoluble pure glucan. Acid and enzymic hydrolyses of the soluble fraction indicate two major glycosidic linkages, $\beta(\mathrm{I} \rightarrow 3)$ and $\beta(\mathrm{I} \rightarrow 6)$, and a little of the $\beta(\mathrm{I} \rightarrow 4)$. Digestion of the residual material by cellulase confirmed the presence of a cellulose-like glucan in these walls. A small amount of laminaribiose and gentibiose confirms the presence of $\beta(\mathrm{I} \rightarrow 3)$ and $\beta(\mathrm{I} \rightarrow 6)$ linkages. Comparable analyses indicate that the walls of both fungi possess similar glucan structures, the differences being quantitative. Proteins in the Phycomycetes walls seem to act as binding points between carbohydrate chains.
\end{abstract}

\section{INTRODUCTION}

Novaes-Ledieu, Jiménez-Martínez \& Villanueva (1967) reported that cell walls of two oomycetes, Phytophthora heveae and Pythium butleri, contained $81-90 \%$ of carbohydrates, glucose being the most abundant sugar. Acid yielded a glucan quickly solubilized in $\mathrm{N}-\mathrm{HCl}$ at $100^{\circ}$ and another resistant to hydrolysis. This last glucan resembled a crystalline cellulose, and accounted for 35 and $25 \%$ of the hyphal walls of $P$. heveae and $P$. butleri, respectively. The current investigation reports more information about the structure of cell wall glucans and the possible role of proteins in the wall.

\section{METHODS}

Organisms, media and preparation of cell wall material. Hyphal walls of Phytophthora heveae and Pythium butleri were prepared as described by Novaes-Ledieu et al. (1967). Mycelium was disrupted in a Ribi fractionator (Sorvall). Cell walls were freed of cytoplasmic material by washing and differential centrifugation. Lipids were extracted from the cell walls by the method of Ballesta (1966) and extracted materials were lyophilized and stored in vacuo at room temperature

Partial acid digestion of cell walls. About $400 \mathrm{mg}$. Phytophthora heveae walls were hydrolysed in $10 \mathrm{ml}$. of $\mathrm{N}-\mathrm{HCl}$ in a boiling water-bath 14 times for $5 \mathrm{~min}$. and finally 5 times for $10 \mathrm{~min}$. Pythium butleri walls were treated with the acid 8 times for $10 \mathrm{~min}$. and 5 times for $15 \mathrm{~min}$. After each operation the digested walls were centrifuged and the residues washed twice with $\mathrm{N}-\mathrm{HCl}$. The combined washings and $\mathrm{HCl}$ extracts were neutralized with $\mathrm{NaOH}$ and stored at $4^{\circ}$.

Cellulolytic hydrolysis of the acid-insoluble fraction. About $50 \mathrm{mg}$. residue in $0.03 \mathrm{M}$ citrate buffer, $\mathrm{pH} 5 \cdot 8$, were homogenized in a MSE ultrasonic disintegrator for 
$30 \mathrm{~min}$. and incubated on a reciprocating shaker for $24 \mathrm{hr}$ at $40^{\circ}$ with roo units of crude Streptomyces QM 814 cellulase (Reese \& Mandels, 1963). The digestion repeated for another $24 \mathrm{hr}$ with fresh cellulase. This enzyme preparation contained a little $\beta(\mathrm{I} \rightarrow 3)$ glucanase but only negligible glucosidase. Phosphoric acid-swollen, Whatman cellulose, prepared following the method of Walseth as described by Bartnicki-Garcia \& Lippman (1967), was used as a control in the enzymic experiments. During incubation the suspensions were protected from bacterial contamination with a layer of toluene. After centrifugation the supernatant liquids were boiled for 5 min. and analysed.

Proteolytic hydrolysis of acid-soluble fraction. Non-dialysable components $(3 \mathrm{mg}$. dry weight) were dissolved in I ml. formic-acetic acid buffer, $\mathrm{pH} \mathrm{2}$, and an amount of crystalline pepsin added to obtain a ratio pepsin:protein of $I: 40$. The mixture was incubated at $37^{\circ}$ for $24 \mathrm{hr}$ under toluene and then dialysed against distilled water at $5^{\circ}$ for a day using cellophane tubing. Dialysable products were analysed by chromatography and electrophoresis.

Analytical procedures. Total carbohydrate was determined by the anthrone procedure (Chung \& Nickerson, 1954) and reducing sugar by the method of Somogyi (1952), using glucose as standard. Quantitative determination of protein was made by the procedure of Lowry, Rosebrough, Farr, \& Randall (I95I), with crystalline bovine serum albumin as standard, and by the ninhydrine method (Moore \& Stein, 1954). Hexosamine was estimated by the method of Rondle \& Morgan (I955) after hydrolysis of the cell wall with $4 \mathrm{~N}-\mathrm{HCl}$ for $17 \mathrm{hr}$ at $105^{\circ}$.

Paper chromatography. Digestion products were desalted on a mixed resin bed (Dowex-I $\times 4$; Dowex-50 $\times 2$ ) and chromatographed on Whatman no. I paper for biose and triose sugars in $n$-butanol + acetone + water $(4+5+\mathrm{I}$ by vol.) for $48 \mathrm{hr}$; ethyl acetate + pyridine + acetic acid + water $(5+5+\mathrm{I}+3$ by vol. $)$ for $36 \mathrm{hr}$; $n$-butanol + pyridine + water $(6+4+3$ by vol.) for $40 \mathrm{hr}$ and detected with aniline hydrogen phthalate in $n$-butanol. Semi-quantitative determination of monosaccharides was made on chromatograms as described by Gottschalk \& Ada (I956). For amino acids, glycopeptides and glycoproteins, butanol + formic acid + water ( $75+15+10$ by vol.) was used for $24 \mathrm{hr}$. Amino compounds were detected with ninhydrin $(0.5 \% \mathrm{w} / \mathrm{v}$, in acetone).

Gentibiose was prepared by paper chromatography of partial acid hydrolysates of postulan, a $\beta(\mathrm{r} \rightarrow 6)$ glucan, extracted from the lichen Umbilicaria pustulata (Lindberg \& McPherson, 1954). Disaccharide was purified with a modification of the procedure described by Reese, Parrish \& Mandels (1962). Laminaribiose and laminaritriose were isolated in a similar way from partial acid hydrolysates of laminarin. The nature of a trisaccharide on a chromatogram was confirmed by elution, followed by second acid hydrolysis and rechromatography of further products. Glucose was assayed with glucose oxidase reagent (Glucostat 'special', Worthington Biochemical Corp., Freehold, New Jersey, U.S.A.).

Zone electrophoresis was carried out on paper (Whatman no. I) or, for components with a high molecular weight subjected to high voltages, on glass-fibre paper (What-

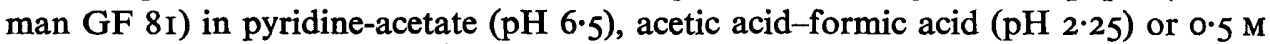
carbonate ( $\mathrm{pH}$ I $.5 ; 750 \mathrm{~V} ; 3 \mathrm{hr}$ ) for amino acids. A borate buffer at $\mathrm{pH} 8.7$ was used to separate gentiobiose and laminaritriose $(2500 \mathrm{~V} ; 2 \mathrm{hr})$. The buffers at $\mathrm{pH} 2.25$ or 6.5 and a $0.5 \mathrm{M}$ sodium tetraborate buffer at $\mathrm{pH} 9.2$ separated glycoproteins (I 500 to 
$2500 \mathrm{~V} ; 2 \mathrm{hr}$ ). Proteins were revealed with amido black (Smithies, 1955) and polysaccharides on glass-fibre paper with $\alpha$-naphtol $\mathrm{H}_{2} \mathrm{SO}_{4}$.

Electron microscopy. Intact cell walls and acid-insoluble fractions of Phytophthora heveae and Pythium butleri were shadowed with an alloy of gold and palladium with a Zeiss EM 9 electron microscope.

Sedimentation diagrams. Sedimentation values were obtained at $59,780 \mathrm{rev} . / \mathrm{min}$. in a Beckman Spinco Model E analytical ultracentrifuge in a $12 \mathrm{~mm}$. aluminium cell at $20^{\circ}$.

Enzymic attack of walls of living oomycetes. Mycelia were suspended in $0.5 \mathrm{ml}$. of $0.05 \mathrm{M}$-citrate buffer, $\mathrm{pH} 6$, containing 0.25 to $0.6 \mathrm{M}-\mathrm{MgSO}_{4}$. Enzyme preparations (usually 125 units) were added and the mixtures incubated at $27^{\circ}$ without shaking. The process was followed by microscopic observations. The $\beta$-glucanases preparations tested were: crude cellulase of Basidiomycete QM 806 grown with cellulose possessing a large amount of $\beta(\mathrm{I} \rightarrow 3)$ exoglucanase; cellulase of Streptomyces QM 8I4 containing a small amount of $\beta(\mathrm{I} \rightarrow 3)$ glucanase; a $\beta(\mathrm{I} \rightarrow 6)$ glucanase of Penicillium brefeldianum QM 1872 (Reese \& Mandels, 1959) also high in $\beta(1 \rightarrow 3)$ glucanase and $\beta$ glucosidase but with very little if any $\beta(\mathrm{I} \rightarrow 4)$ glucanase.

\section{RESULTS}

Partial acid hydrolysis of hyphal walls. The cell walls of Phytophthora heveae and Pythium butleri are very similar in soluble carbohydrate and in percentage of cell wall solubilized by the acid treatment (Table 1 ). Most, if not all, of the protein was in the soluble fractions and represented 6 to I $\%$ of the wall weight. The cell-wall glucosamine was also recovered in the acid-soluble portion.

Table I. Analysis of hyphal walls

Pythium butleri and Phytophthora heveae walls were digested with $\mathrm{N}-\mathrm{HCl}$ as described in the text. Solubilized and residual fractions were analysed.

\begin{tabular}{|c|c|c|c|c|c|c|c|}
\hline \multirow[b]{2}{*}{ Organism } & \multirow{2}{*}{$\begin{array}{c}\text { Initial } \\
\text { weight } \\
\text { (mg.) }\end{array}$} & \multicolumn{2}{|c|}{$\begin{array}{c}\text { Soluble } \\
\text { carbohydrates* }\end{array}$} & \multicolumn{2}{|c|}{$\begin{array}{l}\text { Soluble } \\
\text { protein } \dagger\end{array}$} & \multicolumn{2}{|c|}{$\begin{array}{l}\text { Insoluble } \\
\text { residuef }\end{array}$} \\
\hline & & mg. & $\%$ & mg. & $\%$ & mg. & $\%$ \\
\hline $\begin{array}{l}P . \text { heveae } \\
P \text {. butleri }\end{array}$ & $\begin{array}{l}388 \\
361\end{array}$ & $\begin{array}{l}200 \\
160\end{array}$ & $\begin{array}{l}52 \\
44\end{array}$ & $\begin{array}{l}25 \\
40\end{array}$ & $\begin{array}{r}6 \\
11\end{array}$ & $\begin{array}{l}160 \\
151\end{array}$ & $\begin{array}{l}41 \\
42\end{array}$ \\
\hline
\end{tabular}

* Anthrone positive carbohydrate calculated using glucose as standard.

+ Protein calculated as serum albumin according to the Lowry procedure.

$\ddagger$ Dry weight.

Practically all the protein components of the soluble fractions remained in the cellophane bag during dialysis of $100 \mathrm{ml}$. against 31 . distilled water for $36 \mathrm{hr}$ at $4^{\circ}$. About 22 and $35 \%$ of the soluble carbohydrate of $P$. butleri and $P$. heveae, respectively, passed through the membrane. These results indicate that the $\mathrm{N}-\mathrm{HCl}$ treatment hydrolysed a significant portion of the wall-carbohydrates, whereas it had much less effect on the protein. The fact that most protein was recovered in the soluble fraction suggests an association of glucan and protein in the wall of these two oomycetes.

Dialysable soluble fraction. Qualitative analysis of this fraction showed only carbo- 
hydrate. Glucose was the dominant single sugar though trace amounts of galactose and mannose were identified (more from Phytophthora heveae). Laminaribiose was the principal disaccharide: about $60 \%$ of total disaccharides for Pythium butleri and $70 \%$ for $P$. heveae. The $P$. butleri fraction contained considerably more gentibiose (30\%) than the $P$. heveae fraction. Cellobiose was $6-8 \%$ in $P$. butleri and $12-15 \%$ in the $P$. heveae fraction. A small amount of laminaritriose was found in both.

Non-dialysable soluble fraction. This fraction contained $85 \%$ carbohydrate for Phytophthora heveae and $66 \%$ for Pythium butleri. Protein was $14 \%$ and $33 \%$ respectively. Glucosamine was found exclusively in this fraction. Acid hydrolysates of the same fraction showed not only a high glucose content but also a significant and unexpected amount of mannose ( 8 to $10 \%$ of total monosaccharides). A small quantity of galactose (I-2\% of monosaccharides) was also found for $P$. heveae. Acid hydrolysates of the protein revealed all of the common acids of walls in the usual proportions. In order to calculate approximately the proportion of $\beta(I \rightarrow 3)$

Table 2. Relative amount of di-and tri-saccharides in the various fractions of Oomycetes walls

The oligosaccharides were estimated on paper chromatograms (Gottschalk \& Ada, 1956) after either acid or enzymic hydrolysis (see text).

\begin{tabular}{|c|c|c|c|}
\hline & & P. butleri & P. heveae \\
\hline First acid soluble fraction Non-dialysable & $\begin{array}{l}\text { Laminaribiose } \\
\text { Gentiobiose } \\
\text { Laminaritriose } \\
\text { Cellobiose } \\
\text { Laminaribiose } \\
\text { Gentibiose } \\
\text { Laminaritriose } \\
\text { Cellobiose }\end{array}$ & $\begin{array}{c}+++ \\
++++ \\
++ \\
++ \\
+++++ \\
+++ \\
++ \\
++\end{array}$ & $\begin{array}{c}+++ \\
++++ \\
++ \\
++ \\
++++ \\
++ \\
++ \\
+++\end{array}$ \\
\hline Second acid soluble fraction & $\begin{array}{l}\text { Laminaribiose } \\
\text { Gentiobiose } \\
\text { Laminaritriose } \\
\text { Cellobiose }\end{array}$ & $\begin{array}{c}+ \\
++++ \\
+ \\
+\end{array}$ & $\begin{array}{c}+ \\
++++ \\
+ \\
+\end{array}$ \\
\hline $\begin{array}{l}\text { Supernatant from enzymic hydrolysis of } \\
\text { residue }\end{array}$ & $\begin{array}{l}\text { Laminaribiose } \\
\text { Gentiobiose } \\
\text { Laminaritriose } \\
\text { Cellobiose }\end{array}$ & $\begin{array}{c}++ \\
- \\
+ \\
+++++\end{array}$ & $\begin{array}{c}\frac{+}{-} \\
+ \\
+++++\end{array}$ \\
\hline Residual material & $\begin{array}{l}\text { Laminaribiose } \\
\text { Gentiobiose } \\
\text { Laminaritriose } \\
\text { Cellobiose }\end{array}$ & $\begin{array}{c}++ \\
+++ \\
++ \\
+++\end{array}$ & $\begin{array}{c}+ \\
+++ \\
++ \\
+++\end{array}$ \\
\hline
\end{tabular}

Carbohydrates in percentage: over $80 \%$ of total di-trisaccharides $(++++++)$; 60 to $80 \%$ $(+++++) ; 35$ to $60 \%(++++) ; 10-35 \%(+++) ; 2-10 \%(++)$; less than $2 \%(+)$.

and $\beta(\mathrm{r} \rightarrow 6)$ glucan linkages, we chromatographed a large number of hydrolysates obtained under varying conditions of partial hydrolysis. Pure $\beta(1 \rightarrow 3)$ and $\beta(\mathrm{I} \rightarrow 6)$ glucans were submitted to similar hydrolyses, and the degradation products also chromatographed. An approximate ratio of gentiobiose to laminaribiose of 2 was found for walls of both organisms. In all the chromatograms, a small amount of laminaritriose was encountered while traces of cellobiose were detected, chiefly in $P$. heveae fraction. According to chromatographic and electrophoretic assays, acid hydrolysis of phosphoric acid-swollen cellulose did not release disaccharides in 
appreciable quantity, so the exact contents of $\beta(\mathrm{I} \rightarrow 4)$ linkages in glucan complexes were not calculated exactly. Cellulolytic hydrolysis of fraction components confirmed the presence of $\beta(\mathrm{I} \rightarrow 4)$ linkages and indicated their approximate value. Semiquantitative estimation of the moni, di- and trisaccharides of wall fractions is shown in Table 2. Minor amounts of other oligosaccharides, not resolved, appeared in paper chromatograms. It is possible that sophorose exists in P. butleri walls.

The degree of polymerization of components of two non-dialysable soluble fractions was indicated by values of reducing power (Somogyi, 1952) in relation to the total anthrone carbohydrate content. The percentages obtained $(3.2 \%$ for $P$. heveae and $8.5 \%$ for $P$. butleri) suggested a low degree of polymerization of carbohydrate chains. On the other hand, the sedimentation constants of $2.02 \mathrm{~S}$ for $P$. heveae and $\mathrm{x} .68 \mathrm{~S}$ for $P$. butleri suggested median molecular weights of about 15,000 , which agrees with the behaviour on dialysis. The combined data indicate the presence of non-carbohydrate portion in the the non-dialysable complexes.

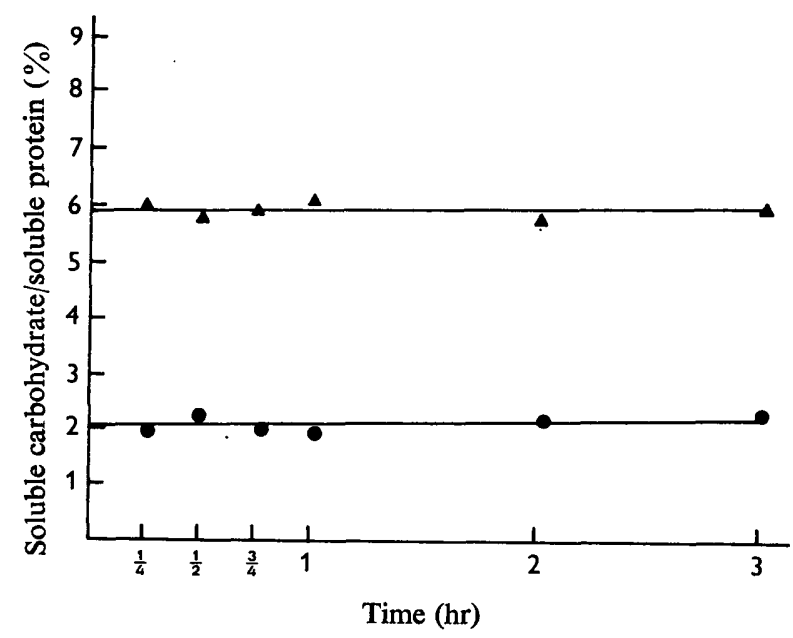

Fig. I. Ratio of soluble carbohydrate to soluble protein extracted with diluted acid from hyphal walls, at various times of hydrolysis: $\bullet, P$. butleri; $\Lambda, P$. heveae.

The ratio of carbohydrate to protein in solubilized components at various times of acid digestion was constant (Fig. I), which permits one to think that protein and carbohydrate were always extracted in constant proportion. Hence a macromolecular glucanprotein complex may exist in the wall.

Glycoproteins were demonstrated in both Phytophthora heveae and Pythium butleri fractions by chromatography in butanol-formic acid and, after elution of the spots without spraying, by electrophoresis at various $\mathrm{pH}$ values; specific reagents for both proteins and polysaccharides were sprayed after cutting the paper into two equivalent strips.

The Phytophthora heveae fraction contained a predominant amido black and $\alpha$-naphthol positive spot of $R_{F}: 0 \cdot 10$. The eluted material was separated at $2500 \mathrm{~V}, \mathrm{pH} 2 \cdot 25$, into two compounds which ran 10 and $15 \mathrm{~cm}$. in $2 \mathrm{hr}$ on Whatman no. I paper when 
placed up to $7 \mathrm{~cm}$. from the anode. For Pythium butleri two main amido black and $\alpha$ naphthol positive spots were detected with respective $R_{F}$ values of 0.08 and 0.12 . The material with the lower $R_{F}$ gave two glycoprotein spots running 8 and $28 \mathrm{~cm}$. on similar electrograms, and the material from the second compound gave a single spot running $35 \mathrm{~cm}$. In both the cases additional spots were detected, which corresponded to glycoproteins in lower concentrations. Complete hydrolysates of material removed from each spot always contained glucose and amino acids.

Control acid hydrolyses of laminarin, laminaribiose, cellulose and cellobiose indicate that gentiobiose does not appear to any significant extent on our chromatograms as a reversion product.

Proteolysis of non-dialysable acid fractions. Both Phytophthora heveae and Pythium butleri yielded similar amino acids and peptides from suspected glucan-protein complexes or protein components, according to the method of Moore \& Stein (1954). Dialysable sugars assayed with anthrone were also similar. Peptic digestion released 20 to $25 \%$ of the total protein. In contrast, only I to $2 \%$ of carbohydrate passes through the dialysis bag after this treatment.

$\beta(\mathrm{I} \rightarrow 3)$ glucanases digestion of isolated walls and soluble non-dialysable fractions. Two $\beta$-glucanase preparations were used to obtain more information about glucan structure of walls: a practically pure $\beta$ (I $\rightarrow 3$ ) endoglucanase from Rhizopus arrhizus and a $\beta(\mathrm{I} \rightarrow 3)$ exoglucanase from Basidiomycete QM 806, here grown with starch. Both the preparations were relatively free of $\beta(\mathrm{I} \rightarrow 4)$ glucanase. Cell walls and soluble fractions of two oomycetes were treated with exo and endo $\beta(\mathrm{I} \rightarrow 3)$ glucanases in $0.05 \mathrm{M}$ citrate buffer, $\mathrm{pH} 4.8$ at $40^{\circ}$, for $4 \mathrm{hr}$ and the products of enzymic hydrolysis studied. Enzymic treatment of each cell wall and its respective soluble non-dialysable fraction with $\beta(\mathrm{I} \rightarrow 3)$ glucanase from $R$. arrhizus did not show substantial digestion of these components, although the glucan linked in $\beta(I \rightarrow 3)$ represents about onethird of the walls. On the contrary, the $\beta(\mathrm{I} \rightarrow 3)$ glucanase from Basidiomycete QM 806 was able to digest isolated walls and soluble acid fractions, and liberate a large amount of glucose.

Purification of the undigested acid-residue. Dry walls of Phytophthora heveae contained $36 \%$ and those of Pythium butleri $23 \%$ cellulosic glucan (Novaes-Ledieu et al. 1967). The ratios of insoluble residue to dry wall, under the conditions specified above, were somewhat higher, particularly for $\boldsymbol{P}$. butleri (Table $\mathrm{I}$ ). The differences might derive from a contaminant glucan that was not digested by acid in the present experiments, so the digested acid residue was subjected to a second acid hydrolysis under more drastic conditions: in $2 \mathrm{~N}-\mathrm{HCl}$ at $105^{\circ}$ for $2 \frac{1}{2} \mathrm{hr}$. Only carbohydrates were present in the totally dialysable supernatant. Anthrone analyses indicated that the glucan digested was $10 \%$ dry-wall weight for $P$. heveae and $23 \%$ for $P$. butleri. Glucose was the only monosaccharide, and gentiobiose the most abundant disaccharide, from $P$. heveae; from $P$. butleri a small amount of galactose was also detected. Both hydrolysates contained laminaribiose and cellobiose.

Enzymic attack of cellulosic residue. The cellulase of Streptomyces dissolved about $70 \%$ of the glucan in the case of Phytophthora heveae and $62 \%$ in Pythium butleri to give mainly cellobiose, but also traces of glucose, laminaritriose and laminaribiose, this last sugar being more plentiful in $P$. butleri. Further enzyme treatment of the residue did not liberate any significant amount of carbohydrate. The material remaining after cellulase digestion was hydrolysed for $4 \mathrm{hr}$, in $2 \mathrm{~N}-\mathrm{HCl}$ at $105^{\circ}$ and chromato- 
graphed. Both had a high content of glucose and gentiobiose as well as lesser amounts of cellobiose. P. heveae yielded traces of laminaribiose and laminaritriose; in P. butleri these amounted to Io to $15 \%$ of solubilized glucan. A component suspected to be sorbose was also encountered in $P$. butleri. In spite of all the treatments a very small amount of the wall still remained insoluble. This material seems to be a complex carbohydrate.

Electron microscopic observation. Intact cell walls of both fungi showed the mass of crossed fibres embedded in an amorphous matrix typical of hyphal walls of fungi. The acid-insoluble residue conserved the fibrillar structure of the original material.

$\beta$-glucanase digestion of living mycelium walls. Nicolas (1965) treated mycelium of two oomycetes, Pythium ultimum and Phytophthora heveae, with a crude cellulase from Trichoderma lignorum, and observed lysis of hyphal walls with release of vacuoles and vacuolated protoplasts. Our studies with Streptomyces and basidiomycete cellulases showed considerable digestion of the walls of the mycelium with both preparations, but only the basidiomycete cellulase liberated protoplasts. Failure to obtain protoplasts with other cellulase preparations may be explained by the presence of proteolytic activity in the enzyme preparation. A Penicillium brefeldianum enzymic preparation, which does not contain cellulase activity, did not dissolve the walls of the living mycelium of the oomycetes studied while showing a large release of reducing sugars in experiments with both isolated cell walls.

\section{DISCUSSION}

The acid-soluble material studied here was a glucan, or glucans, predominantly linked $\beta(\mathrm{r} \rightarrow 3)$ and $\beta(\mathrm{I} \rightarrow 6)$ with an approximate ratio of $\mathrm{I} / \mathrm{I}$, but containing also 5-10\% of $\beta(\mathrm{I} \rightarrow 4)$ linkages. Since parallel hydrolyses of an acid-swollen cellulose showed only minor degradation, we assumed that the $\beta(\mathrm{I} \rightarrow 4)$ linkages came from non-cellulosic glucan. The acid-insoluble fraction revealed mainly $\beta(\mathrm{I} \rightarrow 4)$ glucosidic linkages and also a low content of $\beta(\mathrm{I} \rightarrow 3)$ and $\beta(\mathrm{I} \rightarrow 6)$ glucosidic linkages. This acid resistant glucan was not a pure cellulose as was supposed from preliminary experiments. It could be a glucose polymer of mixed linkage, though dominantly $\beta(\mathrm{I} \rightarrow 4)$, or it could be a mixture of cellulose with another glucan which is very resistant because of a high degree of branching.

The low effectiveness of the $\beta(\mathrm{I} \rightarrow 3)$ endoglucanase from Rhizopus arrhizus on the non-dialysable soluble fraction of two oomycetes walls, containing a considerable percentage of $\beta(\mathrm{I} \rightarrow 3)$ glucan linkages, may be due to the fact that this polymer is highly branched in such a way as to be inaccessible to the enzyme. Besides the digestion of isolated walls and soluble non-dialysable fractions releasing a large amount of glucose when used, a $\beta(\mathrm{I} \rightarrow 3)$ exoglucanase from Basidiomycete $\mathrm{QM} 806$ may suggest that $\beta(\mathbf{I} \rightarrow 3)$ glucan exists in an acid soluble complex as branches, easily attackable by the exoenzyme. On the other hand, the fact that a $\beta(\mathrm{I} \rightarrow 3), \beta(\mathrm{I} \rightarrow 6)$ glucanase preparation from Penicillium brefeldianum degraded isolated walls, with liberation of sugars but not living cells, indicates the presence of resistant glucan, very insoluble in acid, in the outer layer of the cell wall. Our results differ a little from those obtained by Bartinicki-Garcia \& Lippman (1967) with Phytophthora cinnamomi. These authors confirmed, in effect, the presence of cellulosic-glucan in cell walls and reported the existence of glucan(s) soluble in acid, but highly insoluble in alkali, with an undetermined proportion of $\beta(\mathrm{I} \rightarrow 3)$ and $\beta(\mathrm{I} \rightarrow 6)$ linkages. 
Most of the protein of walls was found in the acid-soluble fractions. A chemical extraction of walls with $\mathrm{N}-\mathrm{KOH}$ showed a very low release of carbohydrates (less than $5 \%$, whereas the major portion of protein was solubilized. Hence protein is probably not indispensable to cell wall integrity. Possibly protein units are absent from linear carbohydrate chains but serve to bind them together. This hypothesis is in agreement with the fact that pepsin liberated no nitrogenous material from cell walls, whereas it released a large quantity of peptide and amino acids from acid-soluble material. Mild acid treatment presumably solubilized a glucan and the consequent rupture of carbohydrate linkages made the protein units more accessible to proteolytic digestion. As was published previously (Novaes-Ledieu et al. 1967), the protein of two oomycetes walls contains a significant proportion of hydroxy amino acids and, in the case of Pythium butleri, a high content of aspartic acid. These results could be interpreted as possible binding points between carbohydrate and protein. On the other hand, glucosamine, which has always been found in carbohydrate-protein fractions, could also be a binding point between protein and carbohydrate chains.

The larger protein percentage in Pythium butleri could explain the more drastic treatment necessary to solubilize a glucan-protein complex from the wall of this phycomycete and the different behaviour of the digested material on dialysis.

It may be concluded that the major component in cell walls of the two oomycetes is a glucan-protein soluble in dilute acid. The main chain of carbohydrate may contain various $\beta$-glycosidic linkages, side chains linked $\beta$ (I $\rightarrow 3$ ), and protein chains serving to bind together different glucan molecules. This glucan might form the inner layer of the hyphal walls. In addition both phycomycetes contain an acid-resistant glucan with dominant $\beta(\mathrm{I} \rightarrow 4)$ linkages and a lower content of other kinds of linkages.

The authors are indebted to Dr E. T. Reese for $\beta(\mathrm{I} \rightarrow 3)$ glucanase of Rhizopus arrhizus, and Professor J. R. Villanueva for the facilities and encouragement during the course of this work.

\section{REFERENCES}

Ballesta, J. P. (1966). Caracteristicas de las envolturas celulares de algunas especies de levaduras. Ph.D. Thesis, Facultad de Ciencias, Universidad de Madrid.

BARTNICKI-GARCIA, S. G. \& LiPPMAN, E. (1967). Enzymic digestion and glucan structure of hyphal walls of Phytophthora cinnamoni. Biochim. biophys. Acta 136, 533.

Chung, C. W. \& Nickerson, W. J. (1954). Polysaccharide synthesis in growing yeasts. J. biol. Chem. $208,395$.

GotrschalK, A. \& ADA, G. L. (1956). The separation and quantitative determination of the component sugars of mucoproteins. Biochem. J. 62, 681 .

LINDBERG, B. \& MCPherson, J. (1954). Studies on the chemistry of Lichens. VI. The structure of Pustulan. Acta chem. scand. 8, 985 .

Lowry, O. H., Rosebrough, N. J., FARR, A. L. \& Randall, R. J. (I95I). Protein measurement with the Folin phenol reagent. J. biol. Chem. I93, 265.

MOORE, S. \& STEIN, W. J. (1954). A modified ninhydrin reagent for the photometric determination of amino acids and related compounds. J. biol. Chem. 22x, 907.

Nicolás, G. (1965). Algunos aspectos fisiologicos de hongos hiperparasitos. Ph. Thesis, Facultad de Ciencias, Universidad de Madrid.

Novaes-Ledieu, M., Jiménez-Martínez, A. \& Villanueva, J. R. (1967). Chemical composition of hyphal wall of Phycomycetes. J. gen. Microbiol. 47, 237.

Reese, E. T. \& MANDels, M. (1959). $\beta$-I,3 glucanases in fungi. Can. J. Microbiol. 5, I73. 
Reese, E. T. \& MANDels, M. (1963). Methods in Carbohydrate Chemistry. Ed. by R. L. Whistler. Vol. 3, p. 139. New York: Academic Press.

Reese, E. T., Parrish, F. \& Mandels, M. (1962). $\beta$-D-I,6-Glucanases in fungi. Can. J. Microbiol. 8, 327.

RoNDLE, C. J. M. \& MoRgan, W. T. J. (1955). The determination of glucosamine and galactosamine. Biochem. J. 6r, 586.

SMTTHIES, O. (1955). Zone electrophoresis in starch gels: Group variations in the serum proteins of normal human adults. Biochem. J. 6r, 629.

SomoGYI, M. (1952). Notes on sugar determination. J. biol. Chem. 195, 19. 